\title{
Persons of Colour and the Travel: 12 Years a Slave as the Travel of Blacks
}

\author{
Joyson Jose ${ }^{1}$, Sandra Juliet Jose ${ }^{2}$
}

\author{
${ }^{1}$ Research Scholar, Department of English, Maharaja's College, Ernakulam, affiliated of MG University, Kottay am, Kerala, India \\ Email: jjc911@rediffmail.com \\ ${ }^{2}$ Assistant Professor, Department of English, Sacred Heart College, Chalakudy, Thrissur Dist, Kerala, India \\ Email: jsandrajuliet@ gmail.com
}

\begin{abstract}
Every travel is a search for the exploration of the self. And black travels are no different. The paper is an attempt to explore the agonizing and tormenting journey of the blacks from Africa to the American mainland, where the effect of the travel on the blacks are given an extra emphasis. The historical taintedness of travel writing genre along with the intensity and the challenges of the black travel are deliberated here. The much celebrated slave narrative 12 Years a Slave cannot be just limited as slave narrative. There is a catalyzed orientation and disorientation of the body and the self in these travel writings. It is in fact the life journey of every black in America. More than the struggles the book opens up a strong cultural and political discourse, which defines and re-defines the selfand identity of the blacks.
\end{abstract}

Keywords-Black travel, discourse, identity, self, slave narrative, travel.

"The world is a book, and those who do not travel read only one page" - Saint Augustine

With the emergence of Black Travel Movement and Travel Noire, the black travel has become an act to satisfy the wanderlust. And thus, it reflects the shared interest, the stories of new friendships, the community feeling among them and above all the epic experiences of the new liberated international travel. From being the vulnerable, they were slowly moving towards the limelight. And everything turned out to be more and more of "blacks friendly". Then on, the 'black travel' has become a matter of serious study by all section of academicians, especially with the emergence of these black travels. Prior to these celebrated travels of the Blacks, there were instances of excruciating, tedious and inhumane transportation of Blacks as commodities and goods from the African mainland to various parts of the world.

For so long the major themes around which black travels revolved were that of the racial discrimination, the social reproduction of the fear of racism even in the story telling and the safety instructions, race-related travel choices and above all the concerns of racism. Thus, through the repeated occurrences of many typecast images, the theme of racism has become a cliché in most of the black writings, especially in the travel writings of the eighteenth and nineteenth century. The brutally simple and subtly complex concept called slavery is all-pervasive in these writings. But, from the immovable socio-political positions, the blacks slowly moved to the contours of creative mobility.

Slave narratives are normally considered as a social document about the oppressive condition of slavery and were the first occasion to voice the concerns of the blacks. Pumla Dineo Gqola, in the book What is Slavery to $M e$ ? says about the slave narrative that "we place the slave at the centre of modernity and produce our histories and philosophies from the vantage point, relocating the figure of the slave from silent victim to eloquent critic" [1]. Most of the slave narratives are inevitably the narrative of their travel. Slave narrative has even generated its own subgenre of travel narrative.

In 12 Years a Slave, a memoir of Solomon Northup, he explains how the slaveholding institution limits the life of the black slaves and the resilience and the determination of the black slave to live the life to the fullest possible extent. The acts of self-protection by Northup is not just an attempt for the survival rather it also points to his realization of the real march on to his own self. The life depicted here is the journey of the soul, from freedom to shackles and then to the real freedom of the soul and the self. 
The agonizing and tormenting journey of the blacks from Africa to the American mainland is an oft discussed area in literature, especially through the prior mentioned slave narratives. But the journey of the blacks does not end there. It was just the beginning. They were relentlessly on the move. In a recent account, critics discussed extensively about the black travel after the traumatic American slavery, especially their wanderings after the famous Emancipation Proclamation. For them like Coles, "after the holocaust of American slavery, racism, and the post- Reconstruction terror against African Americans, many African American writers, artists and activists were forced to leave the United States"[2]. In his opinion, it is the prominence of the life- threatening conditions in the United States that became the catalyst of the migrations to African countries, Canada and Europe. Thus, before celebrating the much welcoming "Travel Noire" and similar movements, it is an imperative to study the black travel or the 'coloured travel' during the slavery and afterwards.

In the studies related to the travel writings of the blacks, one of the oft repeated themes is their search for the self, though knowingly or unwittingly. This search for the self, likens to their life struggle. The plight of the blacks of the duality of their African American experiences is incessantly deliberated in this context. The present discourses on the black travels are as sociated with concepts like emancipation of the enslaved community, reidentification of the self and worth of the blacks and even the regeneration or self- reliance of them. According to W. E. B. Du Bois, in his book The Souls of Black Folks:

After the Egyptian and Indian, the Greek and Roman, the Teuton and Mongolian, the Negro is a sort of seventh son, born with a veil, and gifted with second- sight in this American world, - a world which yields him no true selfconsciousness, but only lets him see himself through the revelation of the outer world.... One ever feels his two-ness - an American, a Negro... two thoughts, two unreconciled strivings; two warring ideals in one dark body, whose dogged strength alone keeps it from being torn asunder. The history of the American Negro is the history of this strife, - this longing to attain self- conscious manhood, to merge his double self into a better and truer self.[3]

The cultural discourses of the black travel so far engraved with the tales of captivity and the acts of the dehumanization of the coloured by the whites. The travel here is an attempt to explore the selves of the blacks. The black travel is an invisible genre in travel literature as they do not necessarily confine to the constraints and the conventions of the genre. And also the travel writings of the white men observed a racial insensitivity. The travel's "historical taintedness", as said by James Clifford along with the "unequal encounters, overdetermined routes, contested frontiers, bureaucratic regulations" got an inevitable turn with the emergence of the black writings [4]. These slave travel narratives were the meaningful representation of the blacks as against the whites. It encompassed the intensity and challenges of the black travel.

Just like the ripening process of the anti-colonial resistance, as said by Franz Fanon[5] ; here it was a work that came out during the ripening process of the peak of abolitionist movement in United States of America. And the interpretation and 'gaze' of the blacks to it was much different from that of the writings of the whites. Harriet Beecher Stowe wrote, "it is a singular coincidence that Solomon Northup was carried to a plantation in the Red $[R]$ iver country- the same region where the scene of Uncle Tom's captivity was laid- and where [Northup's] accounts... form a striking parallel" [6].

The 1789 book, The Interesting Narrative of the Life of Olaudah Equiano, or Gustavas Vassa, the African Written by Himself, "the prototype of all subsequent slave narratives" as called by Henry Louis Gates Jr.[7], is a firstperson testimony yet he considers himself as an accidental tourist. But for many critics including Cathy N. Davidson, "there is no more trenchant eyewitness account of late eighteenth- century slavery than the work of Equiano"[8]. It is an intersection of slave narrative and travelogue. Though the discourse is that of a free man, and that the narrator considers himself a tourist, it least limits us from considering the work as merely one that of the struggles of the blacks. The rhetorical deliberations are inexorably defining the embodied discourse. The recurrent images of the slave narratives or their memoirs are getting its shape here. The images of the slave ship, the concept of hole, the growing relevance of that imagery of hole, image of a trickster figure getting appropriated to the later discourses from this work; and that is the significance of the work.

Solomon Northup, a freed man of New York, finds himself in a symbolic "hole" after he travels by ship to Washington DC for a fiddling engagement and is then captured and sold into slavery for twelve years. The "hole" image also changes into a "womb/tomb" symbol on landing 
the 1851 Narrative by Henry Box Brown. Thus, the black narratives deliberate on its own symbols and imagery which clearly reflects the challenges and the temperament of the black writings.

Just like the other travel narratives or slave narratives in 12 Years A Slave, he discusses about the disorderly mobility of the blacks, especially at the time of enslavement, and also about the mundane realities of their travel and life. They are compelled to drench into the path and ways that they dislike or hate. They are clueless about the places to which they are taken to. The uncertainty and insecure nature of their life is well reflected in such travels. The same is the case with Northup, especially during his time as slave. The major theme in slave narratives and in 12 Years a Slave is that of black body discourse and its forms of mobility.

The rhetorical signatures like the loss of Africa as "home" and the "returned body" gets an expression here through the search for one's own freedom. The work emphasizes on the embodying segregation that is experienced by the blacks in all strata of life. The reinforcement of the racial identity gets an extra emphasis during his travels. The racial discrimination of the African Americans and the existence of the institution of slavery get reinforced to his very self through his long wanderings.

In the cycle from a free man to slavery and then to freedom, the narrator exposes his search for self and identity. The conflicted self is much reflected in this journey. The identity of the being the black is reinstated in all his encounters with other slaves. The self of the narrator embraces new dimensions during his journey. Rather than a symbol of progression, the black travel here symbolizes the catalyzed interactions and the disorientation of the self from the body through these interactions. The subjugation for generations, disruption of the self and the imposed limitations for centuries had tremendous impact on the formation of the 'self' in the blacks. Northup feels " the weight of slavery" because he is a hostage; he does not claim to write in order to abolish slavery, but to interpret the events of his life and to itemize the dehumanization that stripped him of his identity and required him to speak to the white men "in the attitude and language of a slave" [9].

In an increasingly racially constrained national milieu, this travel that Northup makes, and similar alike by all the blacks is a symbolic one for political assertion. The time in which the book was written that is during the peak of the Abolitionist movement, can be stated as the testimony to it. The intersection and interaction of both travel and writing contributes to the argument. The travel also unravels his search for social justice and feebly even his journey towards the civil and political rights.

The travel of Solomon Northup is even considered as an instance of cultural continuity rather than a rupture. He was becoming more like that of his fellow brethren from the South. That was the moment of his realization of the struggles of the slaves of the South. The disenchanted selves and the torn-out families are also in a search for their roots. And the search is constantly making them on move. The characters of the memoirs are thus always travelling to find out their own self and for their dear ones. Earlier in the book Northup writes, "he was driven to survive because he had no wish to die "among strangers", but only in the "bosom' of his "family" (p. 83). This points to the ardent desire he holds to go to his home, and even to the roots.

This long neglected literary tradition, travel writing, has got an inevitable literary turn in the 1970s. And with this new shift, the travel writing started to expose the politics behind the perceived, the oft depicted and the constructed culture. Along with that the newly 'acceptable' genre also insisted on the explicit and implicit projections of the self, especially the 'missed representations'. And it is there we read the black slave narratives as their wanderings in search of their self; and 12 Years a Slave is no different. It is an exploration of the self of a black, their sufferings and challenges in life. This travel is for the better understanding self and thereby a 'refinement' of the self. Thus, all the elements of the identity are getting its necessarily reflection there in the work.

\section{REFERENCES}

[1] Gqola, Pumla Dineo. What is Slavery to Me? Postcolonial/ Slave Memory in Post-Apartheid South Africa. Wits University Press, 2010. P.6.JSTOR, www.jstor.org/stable/10.18772/12010045072.

[2] Coles, Robert. Black Writers Abroad: A Study of Black American Writers in Europe and Africa, edited by Graham Russell Hodges, Taylor \& Francis, 1999.p.6

[3] Bois, W. E. B Du. The Souls of Black Folk. A. C. McClurg \& Co., 1903.p.9

[4] Clifford, James. Routes:Travel and Translation in the late Twentieth Century. Massachusetts University Press, 1997.p.39

[5] Boehmer, Elleke. Empire, the National, and the Postcolonial, 1890-1920: Resistance in Interaction. Oxford University Press. 2002.p.1 
[6] Stowe, Harriet Beecher. A Key to Uncle Tom's Cabin. Boston: John P. Jewett \& Co., 1853.p.174

[7] Davidson, Cathy N. "Olaudah Equiano, Written by Hims elf". Novel: A Forum on Fiction, Vol.40, No. 1/ 2, 2006, pp.18- 51. JSTOR, www.jstor.org/stable/ 40267683. p.18

[8] Northup, Solomon. 12 Years a Slave. Starling and Black Publications, 2013. P.183 